\title{
Asymptomatic vertebral fractures in patients with low bone mineral density
}

\author{
Caio Cesar leite de Negreiros ${ }^{1}$, Marina Guareschi Berigo ${ }^{2}$, Robson Luiz Dominoni ${ }^{3 *}$, Deisi Maria Vargas ${ }^{4}$ \\ ${ }^{1}$ Medical Student. Fundação Universidade Regional de Blumenau (Furb), Blumenau, SC, Brazil \\ ${ }^{2}$ Medical Student, Furb, Blumenau, SC, Brazil \\ ${ }^{3}$ Rheumatologist. - Professor at the Department of Medicine. MSc Student, Masters Program in Collective Health, Furb, Blumenau, SC, Brazi \\ ${ }^{4} \mathrm{PhD}$. - Professor at the Department of Medicine, and Lecturer of the Masters Program in Collective Health, Furb, Blumenau, SC, Brazil
}

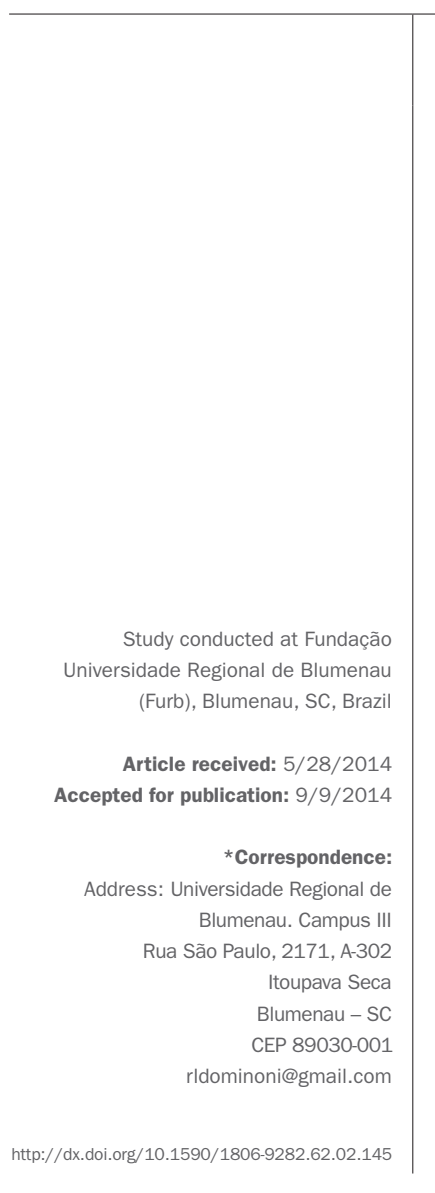

\section{SUMMARY}

Objective: Vertebral fracture assessment (VFA) is a test technique that can be used to detect asymptomatic vertebral fractures (AVF). It uses dual energy X-ray absorptiometry (DXA) and can be performed concurrently with bone densitometry. This study aims to assess the prevalence of AVF in patients with low bone mass.

Methods: Cross-sectional study including 135 individuals with low bone mineral density (BMD) with a T-score < -2.0 standard deviation (SD) in a densitometry clinic located in the city of Blumenau (state of Santa Catarina). Anthropometric, clinical and lifestyle variables were obtained from history-taking and physical examination. Densitometric variables were obtained by bone mineral densitometry and VFA (Explorer, Hollogic ${ }^{\circledR}$ ). Vertebral fractures were classified according to the Genant criteria. Student's t, chi-square and logistic regression were performed for statistical analysis.

Results: AVFs occurred in $24.4 \%$ of the subjects. They were older compared to those without AVF $(65 \pm 9.25$ versus $60.1 \pm 8.66 ; \mathrm{p}=0.005)$, and had a history of lowimpact fractures (38.24\% versus $19.8 \%$; OR $2.5 ; \mathrm{p}=0.03)$. Half of the patients that reported steroid therapy had AVFs, compared to one fifth of those who did not use steroids (50\% versus $21.49 \%$; OR 3.6; $\mathrm{p}=0.01$ ).

Conclusion: Asymptomatic vertebral fractures were present in approximately one fourth of patients. The risk factors associated were history of low-impact fracture, use of steroids and age $>61$ years.

Keywords: Bone density, spinal fractures, osteoporotic fractures, photon absorptiometry, osteoporosis.

\section{INTRODUCTION}

Osteoporosis (OP) is a systemic disease characterized by low bone mass and deterioration of bone tissue microarchitecture, with a consequent increase in fragility. ${ }^{1} \mathrm{Di}-$ agnosis is performed based on the assessment of bone mineral density (BMD) or the occurrence of low-impact fractures in the hip or vertebrae in adulthood. Bone densitometry (BD) is currently the reference examination for diagnosing decreased $\mathrm{BMD}$, and it is done using dual energy X-ray absorptiometry (DXA). ${ }^{2}$

$\mathrm{OP}$ can be primary or secondary. Primary OP is defined as the absence of an identifiable secondary cause. Secondary OP occurs when disease, deficiency or drug is found to be the cause. They include: hypercortisolism (endogenous or exogenous), hyperparathyroidism, hy- perthyroidism, acromegaly, hematopoietic malignancies, primary biliary cirrhosis, inflammatory bowel disease, celiac disease, gastrectomy, homocystinuria, hemochromatosis and inflammatory rheumatic diseases. Fractures are the main clinical manifestations, and vertebral, femoral and forearm are the most frequent. They may be symptomatic, i.e. painful, or asymptomatic. ${ }^{3,4}$

Vertebral fractures are estimated to affect $5 \%$ of Caucasian women older than 50 years, and $25 \%$ of women older than 80 years. ${ }^{5}$ However, about 25 to $35 \%$ of these fractures are asymptomatic. ${ }^{6}$

These fractures can generate socio-economic costs, decrease the quality of life and working time, cause depression, and increase morbidity and mortality. ${ }^{7,8}$ Patients with asymptomatic fractures and low BMD are 25 times 
more likely to experience a new fracture, compared to those with normal BMD and no fractures. A patient with multiple vertebral fractures and low BMD has 75 times greater risk of new fractures. ${ }^{5,9,10}$

The gold standard for diagnosing vertebral fractures is lateral radiograph of the thoracic and lumbar spine but they are usually requested only if there are symptoms such as pain. This type of X-ray demands additional time and resources, as well as greater patient exposure to radiation. Given that about a third of fractures manifests with symptoms, and the request of spine radiographs is not a routine for screening, the diagnosis of vertebral fractures is underestimated. ${ }^{11}$

Vertebral fracture assessment (VFA) is a technique that can be used to detect asymptomatic vertebral fractures. VFA uses DXA, and can be performed with densitometry, allowing rapid evaluation of the vertebral bodies. It can make the diagnosis of vertebral fracture easier and serves as an assessment of risk of future fractures. ${ }^{6}$ VFA can be performed without the need of referral to another service; it involves less exposure to radiation and produces a digital image, which can be stored, enabling analysis at any time for comparison purposes. ${ }^{9}$

The diagnosis of vertebral fractures using VFA is performed when there is a reduction of more than $20 \%$ in anterior, middle, and posterior height. The Genant method (semi-quantitative and visual inspection) is the most used to grade fractures: grade zero or normal, if there is no deformity; grade 1 or mild (20 to $25 \%$ reduction in vertebral height); grade 2 or moderate ( 25 to $40 \%$ reduction in vertebral height); and grade 3 or severe (reduction greater than $40 \%$ in vertebral height). Fractures are still classified as wedge, concave or crush according to the greatest reduction in height in the anterior, middle or posterior vertebral body, respectively.,12

The aim of this study was to determine the prevalence of asymptomatic vertebral fractures in patients with reduced bone mass using the VFA, and to analyze associated factors.

\section{Methods}

This is an observational and retrospective study in 135 patients aged 18 years or older who underwent spine and proximal femur bone densitometry (Explorer, Hollogic $c^{\circledR}$ ) and had low bone mass ( $\mathrm{T}$ score < or equal to -2,00 SD) in at least one bone densitometry site. The VFA exam was performed concurrently with densitometry. The study was conducted at a clinic in the city of Blumenau (state of Santa Catarina) from September 2011 to March 2012.

Quantitative variables were: bone density in the proximal femur (femoral neck and total femur) and lumbar spine (L1 to L4) expressed as T-score; age in years; body weight measured in $\mathrm{Kg}$ using a Plenna ${ }^{\circledR}$ digital scale; height measured in meters using Tonelli ${ }^{\circledast}$ precision stadiometer; body mass index (BMI); daily calcium intake measured in $\mathrm{mg} /$ day based on a dietary record; age at menopause in years. To calculate the daily intake of calcium, the recommendations of Associação Brasileira de Avaliação Óssea e Osteometabolismo (Abrasso) were used: 1 glass of milk $(240 \mathrm{~mL})$ $=300 \mathrm{mg}$ of calcium; 1 glass of yogurt $(240 \mathrm{~mL})=400 \mathrm{mg}$; 1 slice of cheese $(28.35 \mathrm{~g})=200 \mathrm{mg}$; calcium from other sources $=250 \mathrm{mg}$. The tests were performed by a bone densitometry equipment operator certified by the Abrasso and the reports were issued by a clinical densitometrist certified by both the Abrasso and the International Society for Clinical Densitometry (ISCD).

The qualitative variables were gender, presence of $\mathrm{OP}$, presence of obesity, daily calcium intake, history of lowimpact fractures after 40 years of age, current smoker, history of steroid therapy, sedentary lifestyle, presence of menopause and fractures on VFA (in the absence of pain or previous vertebral fracture).

For diagnosis of vertebral fractures, Genant method was used. Genant grade 1, 2 and 3 was considered positive for asymptomatic vertebral fracture, regardless of the type, and Genant grade 0 was considered negative. ${ }^{12}$

Data were organized in descriptive tables containing measures such as frequency, mean, median, standard deviation and coefficient of variation. Estimates of average and proportion (prevalence) were taken at intervals with $95 \%$ confidence. To compare frequencies within the same distribution, chi-square test of adhesion was used. For the association of factors with the occurrence of fractures, chi-square test of independence and odds ratio $(\mathrm{OR})$ were used. In order to compare data between the two groups whose variables were quantitative, Student's t test was used for independent samples. For multivariate data analysis, binary logistic regression procedures were used. In all the tests, the authors considered significant a p-value $<0.05$. Data analysis was carried out using Microsoft Excel 2010 and EpiInfo 2012 version 7 as software.

The study was approved on 12/14/10 by the Research Ethics Committee at Fundação Universidade Regional de Blumenau, protocol number 191/10.

\section{ResUlts}

$24.44 \%(n=33)$ of patients presented asymptomatic vertebral fractures.

Table 1 shows the comparative data of quantitative variables in the groups of patients with and without asymptomatic fractures. There was significant difference in 
TABLE 1 Comparison of patients with and without asymptomatic vertebral fractures including the variables: age, weight, height, BMI, daily calcium intake, age at menopause, densitometry of the femoral neck and spine, and total femur bone mineral density using Student's t test.

\begin{tabular}{|c|c|c|c|c|c|c|c|}
\hline \multirow[t]{3}{*}{ Variables } & \multicolumn{6}{|c|}{ Fracture } & \multirow[t]{3}{*}{$\mathbf{P}$} \\
\hline & \multicolumn{3}{|c|}{ Absent } & \multicolumn{3}{|c|}{ Present } & \\
\hline & $\mathbf{n}$ & Range & Average \pm SD & $\mathbf{n}$ & Range & Average \pm SD & \\
\hline Age & 102 & $(33-79)$ & $(60.01 \pm 8.66)$ & 33 & $(44-82)$ & $(65 \pm 9.25)$ & 0.005 \\
\hline Weight & 102 & $(43.5-91)$ & $(66.28 \pm 10.71)$ & 33 & $(34.5-94)$ & $(64.55 \pm 13.97)$ & 0.454 \\
\hline Height & 102 & $(1.4-159)$ & $(3.13 \pm 15.59)$ & 33 & $(1.5-1.8)$ & $(1.59 \pm 0.07)$ & 0.960 \\
\hline BMI & 102 & $(18.6-39.9)$ & $(26.44 \pm 4.01)$ & 33 & $(14.6-39.4)$ & $(25.51 \pm 5.51)$ & 0.295 \\
\hline Daily calcium intake & 102 & $(300-2346)$ & $(855.19 \pm 324.64)$ & 33 & $(300-1878)$ & $(827.06 \pm 385.16)$ & 0.680 \\
\hline Age at menopause & 102 & $(0-60)$ & $(42.43 \pm 14.71)$ & 33 & $(0-52)$ & $(41.61 \pm 14.82)$ & 0.780 \\
\hline Spine BMD & 101 & $(-4.4--1.2)$ & $(-2.64 \pm 0.56)$ & 33 & $(-5.2--1.1)$ & $(-3.06 \pm 0.91)$ & 0.425 \\
\hline Femoral neck BMD & 102 & $(-3-1.3)$ & $(-1.4 \pm 0.78)$ & 33 & $(-3.6-0.4)$ & $(-2.02 \pm 0.94)$ & 0.000 \\
\hline Total femur BMD & 102 & $(-2.9-0.9)$ & $(-1.28 \pm 0.76)$ & 33 & $(-3.8-1.3)$ & $(-1.79 \pm 1.11)$ & 0.003 \\
\hline
\end{tabular}

I - n: Number of patients; SD: standard deviation.

II - p: P-value for the Student's $t$ test (parametric test for independent samples).

III - If $\mathrm{p}$-value $<0.05$, then differences are significant between groups.

age. In the group with vertebral fractures, age was statistically higher $(65 \pm 9.25$ versus $60.01 \pm 8.66 ; \mathrm{p}=0.005)$.

Bone densitometry of the femoral neck and total femur also showed differences. Femoral neck BMD in patients with vertebral fracture was lower compared to the group without fractures $(-2.02 \pm 0.94$ versus $-1.4 \pm 0.78 ; \mathrm{p}=0.000)$. Regarding total femur, the group with vertebral fractures also had lower BMD compared to the group without fractures $(-1.79 \pm 1.11$ versus $-1.28 \pm 0.76 ; \mathrm{p}=0.003$ ).

Weight, height, BMI, spine BMD, age at menopause and daily calcium intake showed no statistically significant difference between groups.

Table 2 shows the association between the variables studied and the occurrence of asymptomatic vertebral fracture using bivariate analysis with chi-square test and OR. In the analysis, it is concluded that age over 61 years is associated with increased risk of asymptomatic vertebral fracture verified by VFA $(\mathrm{OR}=2.40 ; 95 \mathrm{CI}=1.07-5.40$; $\mathrm{p}=0.031)$. The same is true for steroid therapy $(\mathrm{OR}=3.65$; 95CI=1.18-11.36; $\mathrm{p}=0.018$ ) and history of low-impact fracture $(\mathrm{OR}=2.50 ; 95 \mathrm{CI}=1.07-5.85 ; \mathrm{p}=0.030)$.

Table 3 shows the multiple logistic regression analysis, OR, OR estimate and p-value. Age over 61 years was considered a risk factor for asymptomatic vertebral fractures $(O R=2.40 ; 95 C I=1.07-5.40 ; p=0.034)$, as well as previous steroid therapy $(\mathrm{OR}=3.65 ; 95 \mathrm{CI}=1.18-11.36$; $\mathrm{p}=0.025)$ and previous low-impact fracture $(\mathrm{OR}=2.50 ; 95 \mathrm{CI}=1.07$ 5.85; $\mathrm{p}=0.033)$.

\section{Discussion}

Asymptomatic vertebral fractures were found in $24.4 \%$ of participants. These patients were older than those with- out asymptomatic vertebral fractures (AVF), also presenting history of low-impact fractures more often. Half of the patients that reported use of steroids had AVFs, compared to one fifth of those without steroid therapy $(50 \%$ versus $21.49 \%$; OR 3.65 ; $\mathrm{p}=0.018$ ).

Greenspan et al. evaluated, using VFA, 482 women with no previous diagnosis of fracture. Vertebral fractures were found in $18.3 \%{ }^{6}$ These results relate to our study, which found asymptomatic vertebral fractures in approximately one quarter of patients.

In our study, the mean age of patients with asymptomatic vertebral fracture was higher than in patients without this type of fracture. Steiger et al. studied densitometry data of 172 patients aged 50 years or older. They found that $27 \%$ had vertebral fractures and that these fractures were more frequent in patients over 65 years old. ${ }^{9}$ One possible explanation for these results is the current progressive aging of the population, which increases the chance of occurrence of diseases related to senescence, such as reduction in BMD. ${ }^{10}$

Patients who used steroids had a 3.65 times higher risk of vertebral fractures. Of these patients, $50 \%$ had asymptomatic vertebral fractures. The percentage drops to $21.48 \%$ among patients who did not use steroids. It is not yet established whether there is a minimum dose of steroids safe for bone tissue. Some authors suggest that a maximum dose of $5 \mathrm{mg}$ per day of prednisone (or equivalent) does not have deleterious effects on bone remodeling. However, in a retrospective study, Van Staa et al. documented increase in the relative risk of vertebral fracture with prednisone at doses below $2.5 \mathrm{mg} / \mathrm{day}$, and increased relative risk of fracture in the femoral neck at doses 
TABLE 2 Association between the variables studied and the occurrence of fracture using bivariate analysis with Chi-square test and odds ratio.

\begin{tabular}{|c|c|c|c|c|c|c|c|}
\hline \multirow[t]{2}{*}{ Factors } & & \multicolumn{2}{|l|}{ Fracture } & \multirow[t]{2}{*}{ OR } & \multirow[t]{2}{*}{$95 \mathrm{Cl}$} & \multirow[t]{2}{*}{$c^{2}$} & \multirow[t]{2}{*}{$\mathbf{p}$} \\
\hline & & Present & Absent & & & & \\
\hline \multirow[t]{2}{*}{ Menopause } & No & $12(80 \%)$ & $3(20 \%)$ & 1.3483 & $(0.36-5.1)$ & 0.19480 & 0.658 \\
\hline & Yes & $89(74.79 \%)$ & $30(25.21 \%)$ & & & & \\
\hline \multirow[t]{2}{*}{ Gender } & Female & $98(75.38 \%)$ & $32(24.62 \%)$ & 0.7656 & $(0.08-7.1)$ & 0.05553 & 0.813 \\
\hline & Male & $4(80 \%)$ & 1 (20\%) & & & & \\
\hline \multirow[t]{2}{*}{ History of low-impact fracture } & No & $81(80.2 \%)$ & $20(19.8 \%)$ & 2.5071 & $(1.07-5.85)$ & 4.67979 & 0.030 \\
\hline & Yes & 21 (61.76\%) & 13 (38.24\%) & & & & \\
\hline \multirow[t]{2}{*}{ Smoking habit } & No & $75(75 \%)$ & $25(25 \%)$ & 0.8889 & $(0.36-2.21)$ & 0.06446 & 0.799 \\
\hline & Yes & $27(77.14 \%)$ & $8(22.86 \%)$ & & & & \\
\hline \multirow[t]{2}{*}{ Steroid therapy } & No & $95(78.51 \%)$ & $26(21.49 \%)$ & 3.6538 & $(1.18-11.36)$ & 5.52332 & 0.018 \\
\hline & Yes & $7(50 \%)$ & $7(50 \%)$ & & & & \\
\hline \multirow[t]{2}{*}{ Physical inactivity } & No & $12(80 \%)$ & $3(20 \%)$ & 1.3333 & $(0.35-5.05)$ & 0.18048 & 0.670 \\
\hline & Yes & 90 (75\%) & 30 (25\%) & & & & \\
\hline \multirow[t]{2}{*}{ Age } & $\leq 61$ & $59(83.1 \%)$ & $12(16.9 \%)$ & 2.4012 & $(1.07-5.4)$ & 4.61379 & 0.031 \\
\hline & $>61$ & $43(67.19 \%)$ & $21(32.81 \%)$ & & & & \\
\hline \multirow[t]{2}{*}{ Obesity } & No & $83(76.15 \%)$ & $26(23.85 \%)$ & 1.1761 & $(0.44-3.11)$ & 0.10712 & 0.743 \\
\hline & Yes & $19(73.08 \%)$ & $7(26.92 \%)$ & & & & \\
\hline \multirow[t]{2}{*}{ Adequate daily calcium intake } & No & $90(76.27 \%)$ & $28(23.73 \%)$ & 1.3393 & $(0.43-4.13)$ & 0.25984 & 0.610 \\
\hline & Yes & $12(70.59 \%)$ & $5(29.41 \%)$ & & & & \\
\hline \multirow[t]{2}{*}{ Age at menopause } & $>46$ & $53(75.71 \%)$ & $17(24.29 \%)$ & 1.0180 & $(0.46-2.23)$ & 0.00198 & 0.964 \\
\hline & $\leq 46$ & $49(75.38 \%)$ & $16(24.62 \%)$ & & & & \\
\hline \multirow[t]{2}{*}{ Osteoporosis } & No & $37(84.09 \%)$ & $7(15.91 \%)$ & 2.1143 & $(0.84-5.34)$ & 2.57479 & 0.108 \\
\hline & Yes & 65 (71.43\%) & $26(28.57 \%)$ & & & & \\
\hline
\end{tabular}

- OR: Odds ratio; $\mathrm{Cl}$ : confidence interval (estimative for OR with $95 \%$ confidence interval)

- $c^{2}$. Calculated value (Chi-square test for independence)

III - p: Significance value (If $\mathrm{p}<0.05$, association is significant)

TABLE 3 Factors associated with vertebral fractures $(n=135)$ using bivariate analysis with simple logistic regression.

\begin{tabular}{llll} 
Factors & OR & $\mathbf{9 5 C l}$ & $\mathbf{P}$ \\
\hline Menopause & 1.3483 & $(0.36-5.1)$ & 0.659 \\
\hline Gender (Female) & 1.306 & $(0.14-12.11)$ & 0.814 \\
\hline History of low-impact fracture & 2.5071 & $(1.07-5.85)$ & 0.033 \\
\hline Smoking habit & 0.8889 & $(0.36-2.21)$ & 0.799 \\
\hline Steroid therapy & 3.6538 & $(1.18-11.36)$ & 0.025 \\
\hline Physical inactivity & 1.3333 & $(0.35-5.05)$ & 0.671 \\
\hline Age (> 61) & 2.4012 & $(1.07-5.4)$ & 0.034 \\
\hline Obesity & 1.1761 & $(0.44-3.11)$ & 0.743 \\
\hline Adequate daily calcium intake & 1.3393 & $(0.43-4.13)$ & 0.611 \\
\hline Age at menopause & 1.018 & $(0.46-2.23)$ & 0.964 \\
\hline Osteoporosis & 2.1143 & $(0.84-5.34)$ & 0.113 \\
\hline OR: Odds ratio; Cl: Confidence interval. & & &
\end{tabular}

greater than $2.5 \mathrm{mg} /$ day. ${ }^{13-16}$ In our study, it was not possible to correlate dose of steroids and the presence of fractures, as this variable was not quantified.
Femoral neck and total femur BMD were lower in patients with vertebral fractures compared to patients without vertebral fractures, while density of the spine was not different. Possible explanations are the fact that age-related degenerative bone disease at lumbar spine appears earlier than proximal femur interfering in BMD quantification, and that vertebral fractures can falsely increase BMD, since bone mineral content (BMC) would remain the same while occupying a smaller projected area (DMO $=\mathrm{BMC} /$ area). In a study that included 57 menopaused women, 23 had 1 to 3 fractured vertebrae in the lower back. The average increase in BMD per vertebra was $0.07 \mathrm{~g} / \mathrm{cm}^{2}$, which led to an increase in T-score from -2.3 to $-1.6 .{ }^{17}$ Thus, the presence of fractures could explain the lack of association between vertebral fracture and bone density in the spine, as the accuracy of the method is impaired in this region.

One of the indications for densitometry is the presence of previous fractures, which increases the risk of new fractures by approximately $25 \% .{ }^{10,18}$ In our study, $25.19 \%$ of the participants had a history of low-impact fractures. 
Of these, $38.2 \%$ had vertebral fractures. The authors also found that patients with a history of low-impact fractures have 2.5 times more risk of new fractures, compared to those without history of low-impact fractures.

Asymptomatic vertebral fractures are often underdiagnosed and therefore undertreated. ${ }^{19}$ The optimization of diagnosis might contribute to reduce the occurrence of new fractures, improving the quality of life of patients and reducing treatment costs. ${ }^{20}$

Some risk factors for osteoporotic fractures classically described in the literature were not correlated with the presence of fractures in this study. ${ }^{2}$ For example, in smokers the prevalence of vertebral fractures was $22.86 \%$, while in non-smokers it was $25 \%$. Calcium intake and age at menopause were not different between those with and those without vertebral fractures. The reason is that osteoporosis is a multifactorial disease. Approximately $70 \%$ of the factors involved cannot be changed, i.e. are genetically defined, while $30 \%$ is potentially modifiable and, thus, has to do with environmental issues. ${ }^{21}$

Mean BMI of patients with vertebral fractures was 25.51 compared to the average of 26.44 in those who did not have fractures, although not statistically significant. Increased mechanical load on the skeleton can cause an adjustment in bone tissue to support greater mechanical strength. In these individuals, there is higher production of estrogen by fat cells, with consequent reduction in bone remodeling. Also, increased insulin resistance and hyperinsulinemia are observed in this group. Insulin can have a direct effect on bone formation, but it can also induce greater ovarian production of sex steroids and reduced hepatic production of the protein that binds to sex hormones, leading to increased blood concentration of estrogens and androgens. ${ }^{22}$

$25 \%$ of the sedentary subjects had vertebral fractures, while $20 \%$ of the non-sedentary had these fractures. Therefore, there was no association between physical inactivity and vertebral fractures. According to Pinheiro et al., there are no studies to support this variable as a risk factor for vertebral fractures in the Brazilian population. ${ }^{21}$ The practice of physical activity would impact the increase in BMD, if practiced until reaching a peak in which the individual is subject to gain bone mass. From a certain age, around 30 years, people would only lose bone mass, and physical activity would no longer be relevant. ${ }^{23}$

\section{Conclusion}

A quarter of the individuals had asymptomatic vertebral fractures, which were associated with use of steroids, history of low-impact fractures and age. The evaluation of the spine using VFA concomitant with bone densitometry would be useful in the early diagnosis of vertebral fractures, leading to initiation of treatment, reduced complications and costs, improved prognosis and a better quality of life for patients.

\section{Resumo}

Fraturas vertebrais assintomáticas em indivíduos com baixa massa óssea

Objetivos: vertebral fracture assessment (VFA) é uma técnica de exame que pode ser aplicada na detecção de fraturas vertebrais assintomáticas (FVA). Utiliza absorciometria de raios-X de dupla energia (DXA) e pode ser realizada concomitantemente ao exame de densitometria óssea. Este estudo visa a avaliar a prevalência de FVA em indivíduos com baixa massa óssea.

Métodos: estudo transversal realizado em 135 indivíduos, com baixa densidade mineral óssea (DMO), com T-score $<-2,0$ desvio padrão (DP), em uma clínica de densitometria de Blumenau (SC). As variáveis antropométricas, clínicas e referentes ao estilo de vida foram obtidas por anamnese e exame clínico; as variáveis densitométricas foram obtidas por DMO e VFA (aparelho modelo Explorer, marca Hollogic ${ }^{\circledR}$ ). As fraturas vertebrais foram classificadas de acordo com os critérios de Genant. Os testes estatísticos foram $t$ de student, qui-quadrado e regressão logística.

Resultados: FVA ocorreram em 24,4\% dos indivíduos. A idade desses indivíduos foi superior à dos indivíduos sem FVA $(65 \pm 9,25$ vs. 60,1 $\pm 8,66 ; \mathrm{p}=0,005)$, assim como o antecedente de fratura por baixo impacto $(38,24 \% v s .19,8 \%$; OR 2,5 ; $\mathrm{p}=0,03)$. A metade dos indivíduos que relataram corticoterapia possuíam FVA, contrastando com um quinto dos indivíduos sem corticoterapia ( $50 \%$ vs. $21,49 \%$; OR 3,6; $\mathrm{p}=0,01$ ). Conclusão: fraturas vertebrais assintomáticas estiveram presentes em aproximadamente um quarto dos pacientes. Os fatores de risco associados foram história de fratura por baixo impacto, corticoterapia e idade > 61 anos.

Palavras-chave: densidade óssea, fraturas da coluna vertebral, fraturas por osteoporose, absorciometria de fóton, osteoporose.

\section{References}

1. Ahmed SF, Elmantaser M. Secondary osteoporosis. Endocr Dev. 2009; 16:170-90.

2. National Osteoporosis Foundation. Clinician's guide to prevention and treatment of osteoporosis. Washington, D.C.: National Osteoporosis Foundation, 2013. 
3. Pinto Neto AM, Soares A, Urbanetz AA, Souza ACA, Ferrari AEM, Amaral B, et al. Consenso brasileiro de osteoporose 2002. Rev Bras Reumatol. 2002; 42(6):343-54.

4. Cubas ER, Boeving A, Marcatto C, Santos CMC, Borba CZV, Kulak CAM Principais causas de diminuição da massa óssea em mulheres na pré-menopausa encaminhadas ao ambulatório de doenças ósteo-metabólicas de um Hospital Terciário de Curitiba. Arq Bras Endocrinol Metab. 2006; 50(5):914-9.

5. Lewiecki EM, Laster AJ. Clinical review: clinical applications of vertebral fracture assessment by dual-energy $\mathrm{x}$-ray absorptiometry. J Clin Endocrinol Metab. 2006; 91(11):4215-22.

6. Greenspan SL, Von Stetten E, Emond SK, Jones L, Parker RA. Instant vertebral assessment: a noninvasive dual $\mathrm{x}$-ray absorptiometry technique to avoid misclassification and clinical mismanagement of osteoporosis. J Clin Densitom. 2001; 4(4):373-80.

7. Chapurlat RD, Duboeuf F, Marion-Audibert HO, Kalpakçioglu B, Mitlak $\mathrm{BH}$, Delmas PD. Effectiveness of instant vertebral assessment to detect prevalent vertebral fracture. Osteoporos Int. 2006; 17(8):1189-95.

8. Ginski TP, Newman ED, Hummel JL, Hummer M. Development and evaluation of a vertebral fracture assessment program using IVA and its integration with mobile DXA. J Clin Densitom. 2006; 9(1):72-7.

9. Steiger P, Cummings SR, Genant HK, Weiss H. Morphometric X-ray absorptiometry of the spine: correlation in vivo with morphometric radiography. Study of Osteoporotic Fractures Research Group. Osteoporos Int. 1994; 4(5):238-44.

10. Lipschitz S; National Osteoporosis Foundation of South Africa. Instant vertebral assessment/lateral vertebral assessment: an integral and essential part of osteoporosis assessment. S Afr Med J. 2004; 94(12):967-8.

11. Damiano J, Kolta S, Porcher R, Tournoux C, Dougados M, Roux C. Diagnosis of vertebral fractures by vertebral fracture assessment. J Clin Densitom. 2006; 9(1):66-71.
12. Genant HK, Wu CY, Van Kuijk C, Nevitt MC. Vertebral fracture assessment using a semiquantitative technique. J Bone Miner Res. 1993; 8(9):1137-48.

13. Patrício JP, Oliveira P, Faria MT, Pérez MB, Pereira J. Osteoporose induzida por corticoides. Arq Med. 2006; 20(5-6):173-8.

14. Van Staa TP. The pathogenesis, epidemiology and management of glucocorticoid-induced osteoporosis. Calcif Tissue Int. 2006; 79(3):129-37

15. Van Staa TP, Leufkens HG, Cooper C. The epidemiology of corticosteroid-induced osteoporosis: a meta-analysis. Osteoporos Int. 2002; 13(10):777-87.

16. Van Staa TP, Leufkens HG, Abenhaim L, Zhang B, Cooper C. Use of oral costicosteroids and risk of fractures. J Bone Miner Res. 2000; 15(6):993-1000.

17. Ryan PJ, Evans P, Blake GM, Fogeman I. The effect of vertebral collapse on spinal bone mineral density measurements in osteoporosis. Bone Miner 1992; 18(3):267-72.

18. Brandão CMA, Camargos BM, Zerbini CA, Plapler PG, Mendonça LMC Albergaria B, et al. Posições oficiais 2008 da Sociedade Brasileira de Densitometria Clínica (SBDens). Arq Bras Endocrinol Metab. 2009; 53(1):107-12.

19. Freedman BA, Potter BK, Nesti LJ, Giuliani JR, Hampton C, Kuklo TR Osteoporosis and vertebral compression fractures-continued missed opportunities. Spine J. 2008; 8(5):756-62

20. Cauley JA. Public health impact of osteoporosis. J Gerontol A Biol Sci Med Sci. 2013; 68(10):1243-51.

21. Pinheiro MM, Camargos BM, Borba VZC, Lazaretti-Castro M. FRAX TM: construindo uma ideia para o Brasil. Arq Bras Endocrinol Metab. 2009; 53(6):783-90.

22. Bandeira F. A obesidade realmente fortalece os ossos? Arq Bras Endocrinol Metab. 2007; 51(6):895-97.

23. Reuter C, Stein CE, Vargas DM. Massa óssea e composição corporal em estudantes universitários. Rev Assoc Med Bras. 2012; 58(3):328-34. 